\title{
The Application of English Syllabuses by Teachers of Elementary Education in the Teaching- Learning Process, in Korça Region
}

\author{
MSc. Edlira Xega \\ $\mathrm{PhD}$ candidate \\ Faculty of Education and Philology \\ English Language Department \\ University of Korca, Albania \\ edixega@yahoo.com
}

Abstract

Growing needs for appropriate English learning in Albanian context, the importance of English syllabuses, objectives reflected in the English textbooks, the conformity of syllabuses and the assessment teachers make, conform Common European Framework of References for languages in Elementary education , in urban and rural area, public and non public schools in elementary schools of Korca region, are some elements that lead toward the question: To what extent do Albanian teachers apply the syllabuses in the Albanian context, and how the syllabuses are a point of reference for them and for Albanian learners, for a better language acquisition? The purpose of this research is to conduct an empirical study on the way how Albanian Elementary school teachers aimed at developing their opinions and their practice in the teaching-learning process. A questionnaire survey was adopted as the methodological approach employed in this research. In total, 60 teachers from different public and nonpublic elementary schools, belonging to urban and rural areas in Korca region, participated in this research. It also explored how Albanian teachers of different Elementary schools in Korca region implement the syllabus in their actual classroom language teaching practices and what effect syllabus has on learning outcomes. The questionnaire was conducted in the continuation of a learners' survey, in order to see and observe the teachers' opinions on the English syllabus, the way of organizing classes, how the syllabus is followed, how they adjust it to the textbooks they use, how satisfied they are with them, how they apply them in the educational process. The expected contribution of this research is to observe how the English syllabuses are implemented from the Albanian teachers in elementary education and if they are conform Common European Framework of References for languages (CEFR). The findings of this study provided valuable implications in developing teachers' new ideas for the actual situation of the teaching and learning process.

Keywords: Syllabus, Albanian context, Elementary school teachers, teaching- learning process, public-nonpublic schools, Elementary schools urban and rural areas.

\section{Introduction}

Language is a vital part of the process of knowledge and development. It is a social act, and a control tool between people. The whole process of socialization is a process of the language development. (Patel M.E. Jain M. Praveen, 2008 ; 29)

Language is symbolic, dynamic, a structured and unique system, a career of civilization and culture, as well as a form of social behavior. (Patel M.E. Jain M. Praveen, $2008 ; 31$ )

"The best way to promote efficient language learning is to establish the target language as the language of instruction. To do this teachers need to build up learners' ability to work with speech. One of the most important things is the way teachers communicate with learners. (Dave Willis). (Teaching English- training videos. Teaching speaking DVD training booklet; www.teachingenglish.org.uk)

Foreign languages are a very important process in the Albanian context.

The main concern of this research, is with the syllabuses as the formulation of pedagogical goals, which refer to factors in Albanian educational setting, in general and in Korca region in particular. 


\section{English teaching in Elementary education in Albanian context.}

English Language in Albania is a compulsory subject after the second grade of primary education. The curriculum of basic education in Albania is not organized on the basis of areas but on the basis of subjects,whereas the curriculum of upper secondary education, is organized into learning areas. (Llambiri Stavri et. al; 2011; 11, 16)

Elementary education includes elementary and 9th grade classes. This is a compulsory education and aims to develop intelectual, creative and practial skills of the learners, it develops their personality and equips them with the basic elements of the general culture. Compulsory basic education begins at age 6 and lasts 9 years .It consists of 2 courses: Primary (class I-V) and lower secondary course, (classes VI-IX).

In Albania, the teaching of at least a second language becomes compulsory in public education in the third grade and in private education in first grade of elementary education.

English curriculum for $9^{\text {th }}$ grade school, (Primary education) is designed in accordance with the National Curriculum of Modern Languages of Pre-University Public Education, and in accordance with the European Framework of Reference for Languages in order to response to an open society based on the requirements and needs that lie ahead the teaching and learning process of English language in our country.

This program introduces language skills, communication skills habits and cultural values through which reinforces learners deepen the knowledge acquired in previous classes while increasing its expressive skills in English language. It serves on the overall formation of learners linguistically, socio-culturally and intellectually. Linguistic level rises in a aspiral way, repeating what was explained and developed in the previous years, and by acquiring new knowledge gradually. The program takes into account the age group of learners and their respective characteristics. It includes objectives, lines and sublines not only related to their age and interests, but also stimulate interest and arouse their curiosity for learning English. As an academic subject, foreign language in general and English in particular it is a cultural and skill subject. (Program mësimor për ciklin fillor lënda: gjuhë angleze klasa e tretë, IKT ; 2008)

The weekly norm of the English teacher in the Elementary educational system is 24 classes per week. The realisation of the language objectives in these classes, relies on:

The creation of a real teaching environment, the diversity of the activities, the importance of listening skill, the learning of grammar, the treatment of writing skill as well as the handling of errors.

$2011 ; 7,9)$

Distribution of hours by the respective courses is: (Programet mesimore; lënda Gjuhë angleze IKT 2008-

\begin{tabular}{|c|c|c|c|}
\hline \multirow{2}{*}{ Class } & Hours per week & Weeks & Total \\
\hline III & 2 hours & 35 & 70 \\
\hline IV & 2 hours & 35 & 70 \\
\hline V & 2 hours & 35 & 70 \\
\hline VI & 2 hours & 35 & 70 \\
\hline VII & 2 hours & 35 & 70 \\
\hline VIII & 3 hours & 35 & 105 \\
\hline IX & 3 hours & 35 & 105 \\
\hline
\end{tabular}

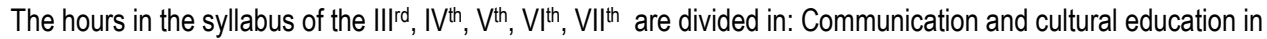
respectively 32 classes/hours, linguistic education 28 classes, and free classes 10classes ;

The hours in the syllabus of VIIIt and IX ${ }^{\text {th }}$ gradesare divided in: Communication and cultural education 57 classes, linguistic education 38 classes and free classes 10 classes.

Total number of classes for elementary school is 560 , compared to approximately the same with the number of classes imposed by Common European Framework of References for languages. 
Besides public education in Korça region there is non - public education.

The expansion of private education service market beyond just private schooling provides sufficient competition as a precondition of improving the quality of such services in general. The risk that competition of private schools to public ones worsens public education service will be prevented by teaching management and performance-based learningteaching process, learners' achievement and transparency of these achievements toward the public and professional opinion. (Strategjia kombëtare e arsimit MASH 2009 - 2013; 33)

Regarding the syllabus of non- public schools in Korça city, is in accordance with the program compiled by the Ministry of Education and Sports.

The division of hours in contrast to public education is respectively:

\begin{tabular}{|c|c|c|c|}
\hline Class & week & Weeks & Total \\
\hline I & 3 hours & 35 & 105 \\
\hline II & 3 hours & 35 & 105 \\
\hline III & 3 hours & 35 & 105 \\
\hline IV & 3 hours & 35 & 105 \\
\hline V & 4 hours & 35 & 140 \\
\hline VI & 4 hours & 35 & 140 \\
\hline VII & 4 hours & 35 & 140 \\
\hline VIII & 4 hours & 35 & 140 \\
\hline IX & 4 hours & 35 & 140 \\
\hline
\end{tabular}

\section{English syllabuses in the Albanian context}

Teaching English syllabuses in the Albanian context, are oriented toward these the aims;

-Take into account the specifics of foreign language.

-They provide a tool for teachers to reflect on practice.

-They Allow a linguistic recycling.

-Encourage interaction between institutions. (Castelloti V, De Carlo M; 1995; 104)

The English syllabuses are built and based on the age groups' interests and characteristics, and it largely contributes in the independent, intellectual and socio-cultural development of the learners.

All the goals, ideas and topics presented in syllabuses, interact with, are more accommodated to each teacher's personality, experience and preconceptions, and result in a teaching style or a plan of action that the teacher seeks to implement in the classroom. (Richards and Nunan (ed.), 2002; 270)

English language syllabus for grades IIIrd-IXth has as object of study English language at the level A1-B1, conform to CEFR (Common European Framework of References) and the creation of stable communicative skills and sociocultural knowledge of learners as initial users of English language from the third grade until the ninth grade of basic education. The program provides teachers with the scheme of A1-A2 level in grades ||$^{\mid r d}-\left.\mathrm{V}\right|^{\text {th }}$ of basic education and distinguishes with grades $\left.\mathrm{VII}\right|^{\text {th }}$ - IX $\mathrm{X}^{\text {th }}$ of basic education, which is a course study belonging to $\mathrm{B} 1$ level ,according to the Common Framework European Reference for Languages.

This English language syllabus in the IIId- IX $X^{\text {th }}$ grades enables the acquisition of this language in the four skills; listening, speaking reading and writing and enables learners:

-to acquire information and recognize the linguistic and cultural reality of the English-speaking countries; 
-to understand the nature of foreign language, relying on the knowledge of the native language;

-to realize links of the foreign language with other subjects. (Kurrikula kombëtare e arsimit bazë program lëndor lënda: gjuhë angleze klasa: III-IX , 2012, MASH , IZHA)

Today the use of methods and techniques of teaching, enables learners prepare for life and society, teach them some skills, such as working independently, having freedom of expression in the English language, being equal among equals in class, being active in various activities organized by schools or classes in English etc.

The skills that learners acquire during English language learning are:

-Linguistic skills

-Communicative skills

-The technological and informative skills.

-Creative and critikal thinking skills;

-The information development skills

- Group working skills;

-The ability of social ethical attitude to be equal to their peers in the world. (Kurrikula kombëtare e arsimit bazë program lëndor, gjuhë angleze III-IX, 2012 (draft) MASH)

If we refer to teaching syllabuses years ago,in the Albanian context, in lesson plans was included the minimal lexic, but the lack of a detailed and concrete experimental work in class, did not answer the demands of the time.

Q. Bedhia and V. Angoni stated :"For example, the syllabuses didn't use to reflect the needs and demands of the professional schools. (Apart from the general literary language, should have been taught technical-scientific language)" (Angoni V. Bedhia Q.1972; 84)

Today with the curriculum is often meant subject syllabus, which is among the key documents for the design of textbooks and the teachers' classroom work. Curriculum must be in full harmony with all the basic documents that define the central curriculum and the principles on which it is built. (Kurrikula kombëtare e arsimit bazë program lëndor lënda: gjuhë angleze klasa: III- IX 2012; 16)

In the past years generally, learning a foreign language in elementary school is viewed by the experimenters as a preparatory stage, with more limited goals, the main goal of which is the preparation of learners to begin a systematic course. (Bedhia Q .1974; 78). Vocabulary and communicative ability of elementary learners were centered around a theme, which had become common for the initial phase of learning a foreign language as family, the classroom with its facilities, the city's socio-cultural facilities. (Bedhia Q .1974; 72)

All the syllabuses are built and based on the age groups' interests and characteristics, and it largely contributes in the independent, intellectual and socio-cultural development of the learners. They aim the linguistic, intellectual and cultural development of the learners, by developing critical thinking learners; independence, by eliciting different forms of individual and group work.

The topics presented in the syllabus, are developed from the teachers and their ideas interact and are accomodated to each teacher's personality, experience, and preconceptions, and result in a teaching style or a plan of action which the teacher seeks to implement in the classroom. (Richards C. Jack and Nunan David, 1997; 270)

These ideas are drawn even from the questions imposed to teachers in the questionnaire.

The syllabus for Grades IIIrd IXth English language of the elementary education has as the object of study levels A1-B1 and the creation of sustainable communication skills and knowledge of students' socio cultural knowledge as initial user of the English language from the third to ninth grade elementary education, according to the Common European Framework of References.

English language syllabus in grades IIIrd- IXth , enables learners of English in all four linguistic aspects (listening, speaking, reading and writing) and help students to acquire information and recognize the linguistic and cultural reality of English-speaking countries, understand the nature of a foreign language, and by relying on the knowledge of the native language to realize the relation of the foreign language with other subjects. ( Programet mësimore për ciklin e mesëm te ulet; lënda: gjuhë angleze, Klasat: III- IX, 2007- 2008) 
Objectives are detailed according to linguistic skills, lines and sub lines. They are observed and measured by the teacher and the learner himself. Setting objectives allows learners to be independent in the learning process.

Objectives according to linguistic skills: Listening, speaking, reading and writing.

Objectives according to lines and sub lines:

Line1: Communication and cultural education Subline1.1: culture and communication, subline 1.2.The actes and the functions of communication;

Line 2 Linguistic education, Subline 2.1: Grammatical structure (Programet mesimore; lënda Gjuhë angleze IKT 2008-2012;|II- IX)

The realization of the above objectives are based on: the creation of a real environment of English learning, diversity of activities, the importance of listening., the knowledge of grammar, dealing with writing, dealing with errors.

In elementary education, learners' assessment is a very important aspect of English in the Albanian context. It's a crucial fact that assessment to be made conform to the types of assessment designed by CEFR, so that they can meet the needs of Albanian learners in the Albanian education system. (Common European Framework of References; Assessment; 2001; 178)

As Widdowson assumes, syllabuses inspire teachers- as well as- Albanian teachers, for introducing methodological innovations in activities' planning and their implementation in the classroom, which are consistent in the conception of the content. What learners do, is not directly determined by the syllabus, but is a consequence of how syllabus is methodologically mediated by the teacher in the pursuit of his own course of instruction. (Widdowson, 2008; 129). This is clearly seen in the results of the Albanian teachers' questionnaire. The main purpose of syllabus reform is to alter the perspectives of teachers, shift their customary points of reference and so provide them with a different set of guidelines. (Widdowson, 2008 ;129). This is what generally the interviewed Albanian high school teachers approve.

\section{Data and Methodology}

\subsection{Data collection}

Data to be collected for this research and for showing results, include syllabus characteristics and effectiveness, so how effective they are when applied directly in the teaching- learning process and the learners' outcomes when applying syllabuses in class.

This questionnaire was developed to see the way how teachers interact with learners, transmit knowledge in the classroom, and the thoughts they share on teaching, syllabus, assessment and learning objectives.

The questionnaire is held with English language teachers of Elementary education working in different public and non-public elementary schools located in urban and rural areas. School teachers who were interviewed belong to different ages and qualifications. Textbooks they use are Albanian and Foreign authors textbooks.

\subsection{The participants in the research}

This research is focused on a questionnaire survey, developed with a significant number of teachers; 15 of them belong to urban areas and 15 to rural ones ( 30 in total). As well as 20 teachers belonging to public schools and 10 to nonpublic ones (30 in total). The target respondents were teachers who have conducted English lessons in Elementary schools, aged between $25-50$ years old (some of them with a considerable experience in teaching process). The total number of the interviewed group of teachers is 60 .

The data derived from the checklist were analyzed by using descriptive statistical methods, displayed in the respective tables parallel to the corresponding graph. Percentages for all items are obtained.

\subsection{Materials}

The data collection instrument for this research is a questionnaire (see appendix). The questions were chosen based on my multiyear teaching experience and based on the problems of the teaching- learning process, especially those having to do with syllabus, assessment, foreign lesson objectives. It consists of 22 alternative, open and closed questions. 


\subsection{Aims of the research}

This questionnaire was conducted in the continuation of a learners' survey, in order to see and observe the teachers' opinions on the English syllabus, the way of organizing classes, how the syllabus is followed, how they adjust it to the textbooks, how satisfied they are with them, how they apply and how they contribute to the realization of the right ideas in education during the learning process of English foreign language in Korça and in its surrounding villages. This approach enables the development of an understanding of the phenomenon from the teacher's view' (Carless 2001; 266)

The appropriate way of teaching is key to success in language education. The aim is to examine Albanian English teachers' attitude toward the English education policy and their own English proficiency.

\subsection{The field of the study}

The field survey was realized in the respective schools. The questionnaires are distributed in late October and early November 2013. It is explained to the teachers the purpose of realizing the questionnaire. A part of the questionnaire was distributed online and may be well said that a part of the teachers were not likely to be answered.

An average of 10 teachers weren't answered online. So the number is reduced to 50 teachers.

From the answers of the teachers results that the average classes size for the urban area is 35 -learners, and for the rural area 20-25- learners. Public classes in elementary education contain an average number of 30 learners and non-public schools a number of 15 learners.

\subsection{Research design}

The methodology applied in this research is qualitative and quantitative. As Paille has pointed out:" The qualitative methodology, constructivist methodologies are carriers of theoretical and methodological innovations that would renew the general interest of policy makers, practitioners and researchers in the humanities and social sciences. ( Mucchielli A. 2005; 7)

The teachers' answers are interpreted through statistics and are displayed in graphs. Their explanations are a way that helped us a way to realize a certain "understanding" of the phenomenon (Mucchielli A. 2005; 9), in our case that of the syllabuses implementation in teaching- learning process in elementary education.

It is a quantitative study, based on the questionnaire survey.

This research led to a separation of roles; the researcher as the producer of truth on the one hand and the English language teacher as a consumer of it on the other. (Widdowson; 2008; 55). And a new significance is given to the everyday problems and aspects of teaching- learning process that are faced by teachers.

\subsection{Empirical Analysis}

Language awareness is essential for understanding; knowing about a language, for a teacher is more important than knowing a language. (Jenkins; 2006)

The questionnaires clearly define facts or opinions which have been identified by more qualitative methods. (Woods P.; 2006)

There are given the data of the interviewed Albanian teachers of English in Elementary schools.

Questions are grouped according yes / no, percentages, questions assessing the language skills, objectives, monitoring and implementation of the syllabus. The questionnaire consisted of 22 questions.

Results are presented in graphs, by comparing the replies of teachers belonging to different schools. As for any quantitative data, descriptive statistics were used. As for any qualitative data analysis, the open-ended questions were translated and coded into general categories.

For data and quantitative analysis are used descriptive statistics, for qualitative analysis the questions are analyzed in the general and specific categories. The development of interpretive and reflective skills offers a very practical and fruitful alternative for language teacher education. (Sauvignon $2003: 64$ ) 


\section{The interpretation of the questionnaires.}

\subsection{The interpretation of the questionnaires held with English teachers, elementary education, part of public and non public schools, urban area.}

From the interviewed 30 Elementary schools English teachers, belonging to public and nonpublic schools, it results that the public Elementary school teachers, are more sufficiently satisfied than the non public Elementary school teachers, compared to the fact that the last ones are more satisfied than the public Elementary school teachers.

Based on the these teachers' opinions, syllabus is conform the learners' level, compared to a lower percentage of non public Elementary school teachers, who do not share the same opinion.(Table 1, Graph 1). Refer at the end of this article.

Referring to the statistics in table 2 and graph 2, among the grouped questions one consists in the place that culture takes in the syllabus. From 30 interviewed teachers, the highest percentage of the teachers in non public elementary schools, believe that culture takes $20 \%$ in the syllabus, meanwhile a percentage of $33 \%$ of elementary public schools teachers, believe that culture takes an important place in the English syllabuses, concretely $40 \%$. Most of the teachers of public elementary schools think that culture takes $80 \%$ of the syllabus.

The question having to do with how much the syllabus consider the age and level of the learners, the elementary nonpublic school teachers, have the highest percentage of $80 \%$, compared to $40 \%$ of Elementary public school teachers.

Regarding to the question that the syllabus objectives are reflected in the textbooks, $16 \%$ of Elementary public school teachers, are of the opinion that the syllabus objectives, take a place of $20 \%$ and $60 \% ; 33 \%$ of these teachers support the fact that the objectives take $80 \%$ and $33 \%$ of them, are for $100 \%$. The highest percentage of $75 \%$ of nonpublic elementary school teachers, believe that the objectives of the syllabus are reflected $100 \%$ on the textbooks. This fact is related with the textbooks that these teachers use; foreign authors' textbooks reflect in a higher percentage the syllabus objectives, compared with the Albanian authors' textbooks.

Of high interest is the question related to the syllabus conformity with CEFR (criteria of Common European Framework of References for languages). $33 \%$ of Elementary public school teachers believe that it is conform $60 \%, 33 \%$ of them believed that the syllabus is conform CEFR $80 \%$ and also $33 \%$ believe that it is conform $100 \%$. , compared to a higher percentage of the non- public elementary school teachers, who are of the opinion that the syllabus is conform $100 \%$ to CEFR.

Below, in the presented statistics, it is also clear that a higher percentage of non public elementary school teachers, realize $80 \%$ the syllabus and elementary public school teachers, realize $100 \%$ the syllabus. (Table 2, Graph 2).

In table 3 and graph 3, based on the teachers' opinions, the learners' age is taken into consideration when compiling the syllabus. $100 \%$ of non- public elementary school teachers believe that the objectives of CEFR are reflected in the syllabus, compared to $33 \%$ of public elementary school teachers who share the idea that the objectives of CEFR are not reflected in the syllabus.

$75 \%$ of non- public elementary school teachers believe that objectives can be reached in classes with a great number of learners. For public elementary school teachers, the percentage is $50-50 \%$.

Learners' assessment is a very important aspect in teaching learning process in the Albanian context. It is essential that the assessment is conducted in conformity with the types of evaluation set out by CEFR, so that they fit better to the needs of learners in the Albanian educational system. (Common European Framework of References (Assessment); $2001 ; 179)$

Based on the teachers' answers in these schools, the highest percentage in schools' teachers, public and nonpublic, assessment is made based on CEFR criteria; respectively $66 \%$ Public Elementary school teachers and $75 \%$ nonpublic elementary school teachers. But it was also a relatively not low percentage that assessment is not based on CEFR. Learners are introduced with the lesson objectives by all the teachers in both schools.

The teachers pretend that they pay attention to the tasks they impose to learners, in order to reach their objectives. Usually they include tasks that involve cognitive processes such as selecting, reasoning, classifying, sequencing information, and transforming information.( Ellis R. 2003; 8)

The other group of questions has to do with the set of objectives and with the fact how much the teachers take into the consideration the learners' opinion about the syllabus. Elementary non public school teachers place the objectives 
in every class, by dividing them in minimal and maximal objectives. As well as $83 \%$ of elementary public school teachers set the objectives in every class. Only a small percentage, $16 \%$, set them at the beginning of each module.

Public Elementary schools teachers take more in consideration the learners' opinion in the development of the lesson, compared to the nonpublic elementary school teachers. The syllabus is followed $66 \%$ from public Elementary schools teachers and $75 \%$ from nonpublic elementary school teachers. (Table 4 and graph 4 )

\subsection{The interpretation of the questionnaires held with English teachers, elementary education,} part of urban and rural areas.

The same questions are analyzed for this group of teachers too. Their answers are various. Tables and graphs show statistically their replies.

Referring to the question how satisfied are the teachers with the syllabuses, and how the syllabus is conform the learners' level, the results indicate that Elementary school teachers, rural area, are very satisfied and those of urban area are sufficiently satisfied. The syllabus is sufficiently conform the learners' level for the opinion of Elementary school teachers, rural area, compared to $75 \%$ of Elementary school teachers, urban area, who believe that the syllabus is in complete conformity with the learners' level.(Table 5 and Graph 5)

Table 6 and graph 6 show the result sorted by being based on problems and aspects having to do with the cultural aspect and its treatment in the English language teaching - learning process, in what percentage is the learners' age taken into consideration, the conformity of the syllabus with the criteria set by CEFR, and in what percentage the syllabus is realized by this group of teachers.

Most of the Elementary school teachers, rural area, $75 \%$ share the opinion that cultural aspect covers $40 \%$ of the syllabus, compared to $66 \%$ of Elementary school teachers, urban area who say that culture covers $80 \%$ of the syllabus.

The largest percentage of Elementary school teachers, urban area think that the age and level of the learners are taken $80 \%$ in consideration, while syllabus is compiled, compared to $75 \%$ of Elementary school teachers, rural area who are of the opinion that it is taken into account to the extent of $60 \%$.

Regarding to the reflection of the syllabus objectives in textbooks, the highest percentage in both groups of teachers (33\% from urban $50 \%$ in rural); urban and rural area, believe that they are reflected in a mass of $60 \%$. This also depends on the textbook that they use. As it is seen from the statistics and replies of the questionnaire, foreign authors textbooks, reflect in a higher degree the objectives.

The conformity of the syllabus with CEFR according to $50 \%$ of Elementary school teachers, rural area the syllabus is conform CEFR in a mass of $60 \%$, whereas $33 \%$ of Elementary school teachers, urban area are of the opinion that the syllabus is conform CEFR in a mass of $60 \%, 33 \%$ believe $80 \%$ and the rest $100 \%$.

The syllabus is realized and followed $100 \%$ from $100 \%$ of Elementary school teachers, rural area and $100 \%$ from $66 \%$ Elementary school teachers, urban area.

The specification of syllabus content was derived from formal models of linguistic description. The implication for teaching is that methodology should ensure that classroom language and objectives set, is as close an approximation to authentic language behavior as possible. (Widdowsson 2008; 130)

From the data taken from table 7 and graph 7 , the age of learners is taken into consideration during the syllabus compilation. Only a percentage of $16 \%$ of Elementary school teachers, urban area believe that it is not taken into consideration. According to $100 \%$ of Elementary school teachers, rural area the objectives can be reached in classes with a great number of learners, compared to $50 \%$ of Elementary school teachers, urban area who believe that the objectives are unattainable in classes with a great number of learners. Actually Elementary school teachers, rural area do not deal with this situation, because their classes are relatively with a small number of learners, so the opinion of Elementary school teachers, urban area is more convicting.

$100 \%$ of Elementary school teachers, rural area assess based on CEFR criteria, compared to $66 \%$ of Elementary school teachers, urban area. Both groups of teachers introduce learners with the lesson objectives. 
Many teachers support the idea of Widdowson that syllabus offers security. (Widdowson 2008; 152). $100 \%$ of Elementary school teachers, rural area and $83 \%$ of Elementary school teachers, urban area, set the objectives in every class; only $16 \%$ of them set the objectives at the beginning of each module.

Based on the answers of $66 \%$ of Elementary school teachers, urban area, and $75 \%$ of Elementary school teachers, rural area, the syllabus is followed by them, but not strictly. (Table 8 and graph 8).

\section{Conclusions. Comparison of results}

The general purpose of education is to initiate people in a secondary culture. This is what is drawn even from the replies of teachers in the questionnaire; the fact that they use, follow and are widely based on the syllabus. So if the learners are to be induced into formal learning they are likely to need some definite direction which will indicate the paths they are to follow. This is what the syllabus can provide. (Widdowson 2008; 152)

The results of this study suggest that all the elementary education teachers in the Albanian context follow even though not strictly the syllabuses designed by ICT, Ministry of Education and Sport in Albania. This study has asserted how the Albanian teachers have the right to make judgments and how these judgments affect decision-making in syllabus design.

From the survey questionnaire it is observed that most of teachers at least have positive attitudes toward the syllabus conformity to the learners' level in the classes where they teach.

An important aspects of the existing situation in the Albanian context, is how curriculum outcomes agreed at present frequently using language, ideas and approaches imported from English-speaking cultural settings, can best be articulated and communicated in terms that maximize their 'cultural continuity', (Holliday 2001) and so are meaningful to the participants of the Albanian context, who will need to understand them if they are to be achieved.

The main conclusions that can be drawn from this research are:

- For teachers of Elementary Public and non-public schools, the syllabus is applied and is fully realized. The syllabuses objectives are presented in textbooks, more supporters of this, are teachers of public schools, especially those who use in foreign authors' textbooks in a mass of $80 \%$ and $100 \%$. A high number of teachers from both schools, set objectives in every class. Furthermore, teachers of non- public schools are very satisfied with the existing syllabuses. Even the teachers of public schools, a considerable percentage of whom support the conformity of them with the learners' age and level, as well as the involvement and the treatment of intercultural aspects in the syllabus.

However based on the opinion of the teachers from both schools there is still an insufficiency in the assessment aspect; it is not fully realized, based on the standards set the CEFR.

- For teachers of elementary urban and rural schools area, the conformity of syllabus with learners' age and level is sufficiently in $100 \%$ of the teachers of rural schools areas, whereas they are a lot in conformity according to most of the teachers' of urban areas opinion. Considering the syllabus conformity with CEFR criteria, has the higher percentage of teachers' urban area schools opinion.

Syllabus is realized $100 \%$ from the teachers of both schools. Regarding the syllabus objectives in textbooks, they appear $100 \%$ according to urban area teachers, whereas the teachers of rural areas school share the opinion that they appear $50 \%$. This may simply leads to the fact that as well as even in the first group of teachers (public and nonpublic), this depend on the textbook they work with; the foreign authors' textbooks treat and include the syllabus objectives in them.

An interesting fact that isn't expected, is that a high percentage of teachers in schools of rural area, assess based on the CEFR criteria. Maybe this depends on the criteria required and used by the foreign authors' textbooks they use. Also a large percentage of teachers in rural area, set objectives in every class, compared to a lower percentage of teachers in urban area. A considerable number of teachers in both school groups take into consideration learners' opinion for the syllabus.

Therefore, teacher education syllabuses should deal with language teaching methodology appropriate to a range of learner ages and stages. This is put in use in the groups of teachers taken into question. I believe that it is essential for teachers to know how to localize the existing curriculum to make it fit in their particular contexts. 
It is needed to develop clear learning objectives and detailed guidelines for what should be taught, including why and how, and also needs to make these guidelines available to all teachers and schools.

However it is only a small sample and the answers should not be generalized, these are some of the ideas of some teachers. Although document analysis was employed and data were analyzed quantitatively and qualitatively, it would have been interesting to have class observations and interviews or meetings with more teachers.

The design of this study and the questions in the questionnaire are rather exploratory in nature. It attempts to examine elementary school teachers' needs and wants.

Further studies on teachers' needs and opinions should be pursued to meet the various and constantly changing teaching conditions and situations, in order to lead to a professional teaching.

\section{References}

Angoni V., Bedhia Q. (1972) .Mbi mësimin e gjuhëve të huaja. Revista pedagogjike nr. 3 ; 84-95

Bedhia Q. (1974) Gjuha e huaj dhe nxënësit e ciklit të ulët të shkollës 8- vjecare.Revista Pedagogjike, nr.2; 78

Carless,D. ( 2001), "A case study of curriculum implementation in Hong Kong" In Hall, D. \& Hewings, A. Innovation in English language teaching: a reader. London: Routledge.

Castellotti V. De Carlo M. (1995) "La formation des enseignanats de langue" cle international didactique des langues etrangeres.

Common European Framework of References; ( 2001); 177- 197

Ellis R.,(2003) "Task- based language learning and teaching", Oxford, University press,

Holliday, A. (2001). Achieving cultural continuity in curriculum innovation. In Hall, D.R., \& Hewings, A. (Eds.) (2001). Innovation in English Language Teaching (pp169-177). London : Routledge,.

http://www.arsimi.gov.al/al/arsimi/shkolla/nxenesit

Jenkins J. (2006) Current perspectives on teaching word Englishes and English as a lingua franca TESOL quarterly 40 (1) (157- 181)

Kurrikula kombëtare e arsimit bazë program lëndor lënda: gjuhë angleze klasa: III- IX (2012), Tiranë, MASH ,IZHA

Llambiri S.Abdurrahmani T. Mulla A. (2011) Analiza krahasuese e kurrikulës aktuale të arsimit bazë me atë të vendeve të tjera' MASH,

Mucchielli A. (2005) Le développement des méthodes qualitatives et l'approche constructiviste. Recherche qualitative et production de savoirs, - Hors-Série - Numéro 1 Actes du colloque (7, 9-31)

Patel M.E. Jain M. Praveen (2008) "English language teaching "Methods, tools and techniques, Sunrise publishers and distributors, (I)

Programet mesimore per ciklin e mesem te ulet; lënda Gjuhë angleze 2008-2011; Klasat III-IX; (2008) ,IKT

Programet mësimore për ciklin e mesëm te ulet; lënda: gjuhë angleze, Klasat: III- IX, 2007- 2008

Richards, J \& Nunan D. (ed.) (2002). Second Language teacher education. Cambridge University press.

Sauvignon, S. (2003). "Teaching English as communication": A global perspective World Englishes

Strategjia kombetare e arsimit parauniversitar 2009- 2013, (2009) Tirane Republika e Shqiperise , Ministria e Arsimit dhe Shkences.

Teaching English- training videos. Teaching speaking DVD training booklet; www.teachingenglish.org.uk

Widdowson H.G. (2008) Aspects of language teaching, Oxford Univesity press

Woods Peter, "Qualitative Methods" Faculty of Education, University of Plymouth, 2006

\section{Tables and Graphs}

Table 1. Teachers of elementary public and non-public schools 


\section{Elementary public school Elementary non-public school}

\begin{tabular}{lccc}
\hline Sufficiently satisfied with the syllabus & & $66 \%$ & $50 \%$ \\
\hline Very satisfied with the syllabus & $33 \%$ & $50 \%$ & $16 \%$ \\
\hline Conformity with the learners'level/sufficiently & $83 \%$ & $25 \%$ & \\
\hline Syllabus conformity with the learners' level/ a lot & $75 \%$ & & \\
\hline
\end{tabular}

\section{Graph 1}

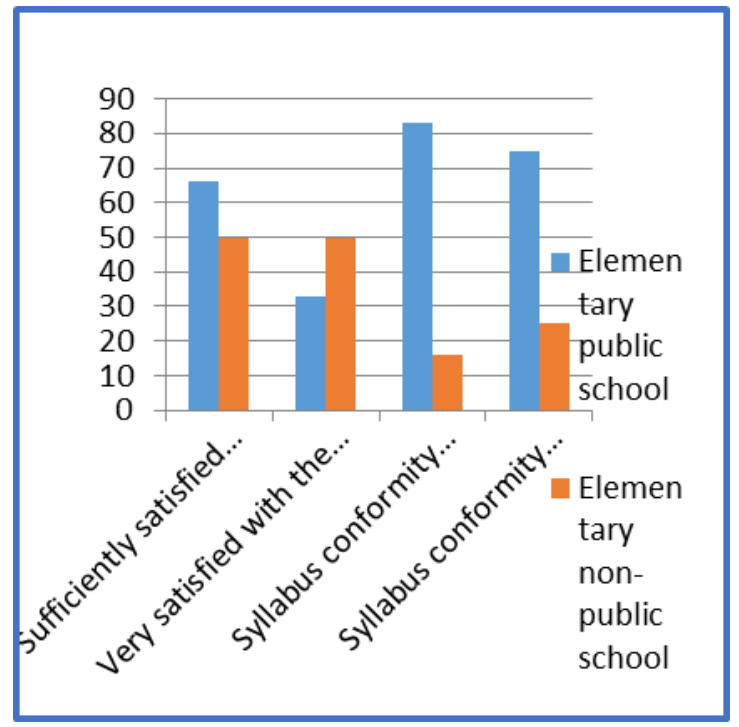

Table 2. Teachers of elementary public and non-public schools

\begin{tabular}{|lll|}
\hline & Elementary public school(\%) & $\begin{array}{c}\text { Elementary } \\
\text { public school(\%) }\end{array}$ \\
\hline Culture in syllabus $20 \%$ & $0 \%$ & $50 \%$ \\
\hline Culture in syllabus $40 \%$ & $33 \%$ & $0 \%$ \\
\hline Culture in syllabus $60 \%$ & $0 \%$ & $25 \%$ \\
\hline Culture in syllabus $80 \%$ & $66 \%$ & $25 \%$ \\
\hline Considering the learners'age/level $40 \%$ & $33 \%$ & $0 \%$ \\
\hline Considering the learners'age/level $80 \%$ & $66 \%$ & $100 \%$ \\
\hline Syllabus objectives in textbook $20 \%$ & $16 \%$ & $0 \%$ \\
\hline Syllabus objectives in textbook $60 \%$ & $16 \%$ & $0 \%$ \\
\hline
\end{tabular}


European Journal of Social Sciences Education and Research
September-December 2014

Volume 1, Issue 2

\begin{tabular}{|lll|}
\hline Syllabus objectives in textbook $80 \%$ & $33 \%$ & $25 \%$ \\
\hline Syllabus objectives in textbook $100 \%$ & $33 \%$ & $75 \%$ \\
\hline Syllabus conformity with CEFR $60 \%$ & $33 \%$ & $0 \%$ \\
\hline Syllabus conformity with CEFR $80 \%$ & $33 \%$ & $25 \%$ \\
\hline Syllabus conformity with CEFR $100 \%$ & $33 \%$ & $75 \%$ \\
\hline Syllabus realization $80 \%$ & $33 \%$ & $75 \%$ \\
\hline Syllabus realization $100 \%$ & $66 \%$ & $25 \%$ \\
\hline
\end{tabular}

\section{Graph 2}

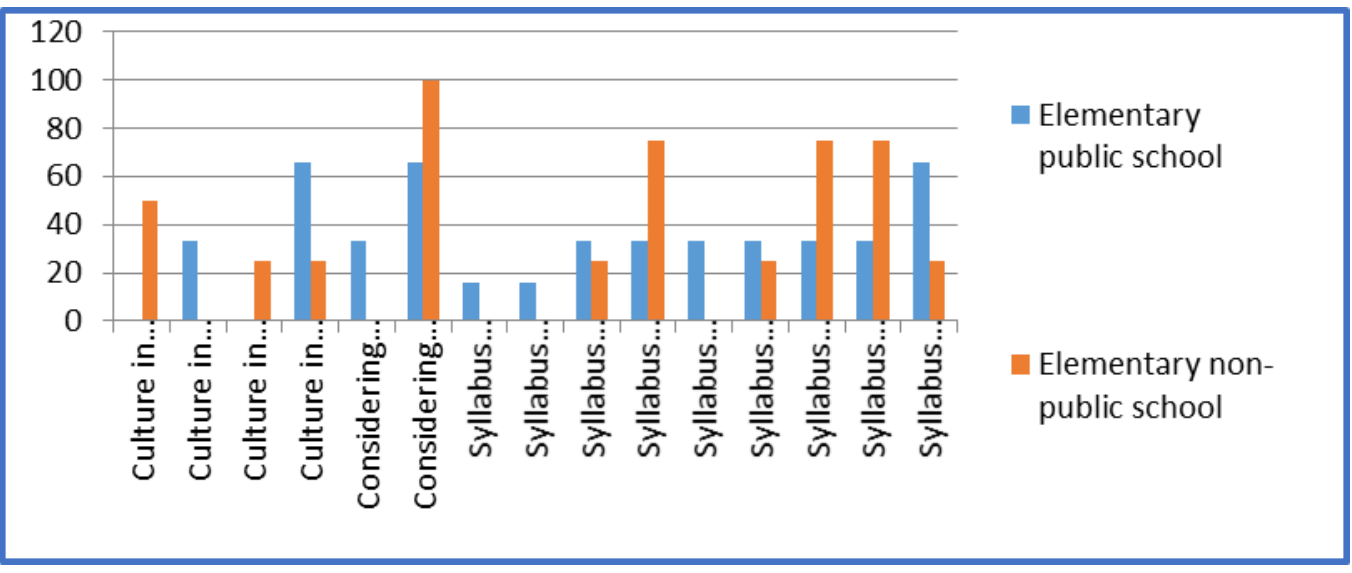

Table 3. Teachers of elementary public and non-public schools

\begin{tabular}{|lll|}
\hline & Elementary public school (\%) & $\begin{array}{c}\text { Elementary } \\
\text { public school (\%) }\end{array}$ \\
\hline Considering the learners' age & $100 \%$ & $100 \%$ \\
\hline Objectives presented in textbooks & $83 \%$ & $100 \%$ \\
\hline Objectives not presented in textbooks & $16 \%$ & $0 \%$ \\
\hline CEFR objectives in syllabus & $33 \%$ & $100 \%$ \\
\hline CEFR objectives not in syllabus & $33 \%$ & $0 \%$ \\
\hline $\begin{array}{l}\text { Objectives can be reached with a great } \mathrm{nr} \text { of } \\
\text { learners }\end{array}$ & $50 \%$ & $75 \%$ \\
\hline $\begin{array}{l}\text { Objectives can not be reached with a great } \mathrm{nr} \text { of } \\
\text { learners }\end{array}$ & $50 \%$ & $25 \%$ \\
\hline Assessment conform to CEFR/Yes & $66 \%$ & $75 \%$ \\
\hline Assessment conform to CEFR/ No & $33 \%$ & $25 \%$ \\
\hline Introducing learners with objectives/Yes & $100 \%$ & $100 \%$ \\
\hline
\end{tabular}




\section{Graph 3}

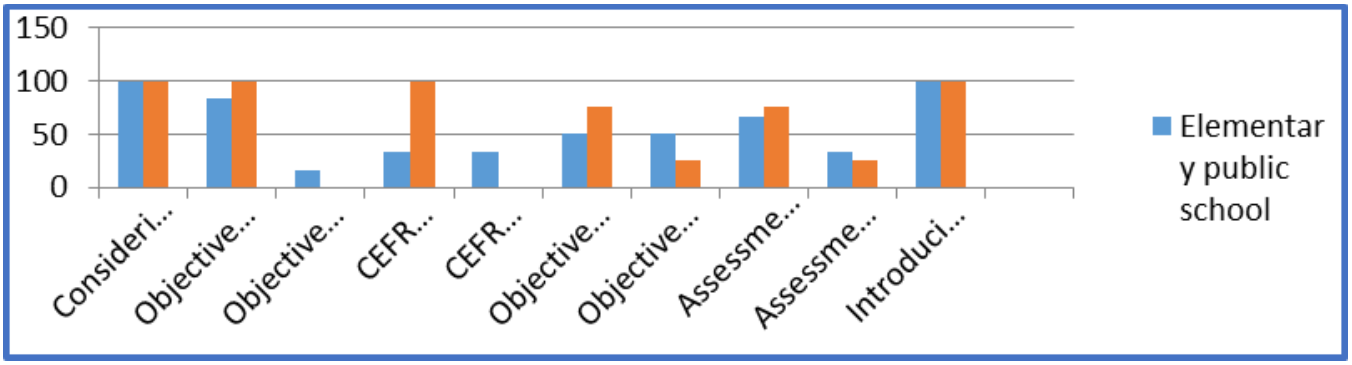

Table 4 Teachers of elementary public and non-public schools

\begin{tabular}{|lcc|}
\hline & Elementary public school \% & Elementary non-public school \% \\
\hline $\begin{array}{l}\text { Objectives are set in every } \\
\text { class }\end{array}$ & $83 \%$ & $100 \%$ \\
\hline $\begin{array}{l}\text { Objectives are set at the } \\
\text { beginning of each chapter }\end{array}$ & $16 \%$ & $25 \%$ \\
\hline $\begin{array}{l}\text { Considering } \\
\text { learners'opinion for the } \\
\text { syllabus }\end{array}$ & $33 \%$ & $75 \%$ \\
\hline $\begin{array}{l}\text { Following the syllabus/not } \\
\text { strictly }\end{array}$ & $66 \%$ & \\
\hline
\end{tabular}

Graph

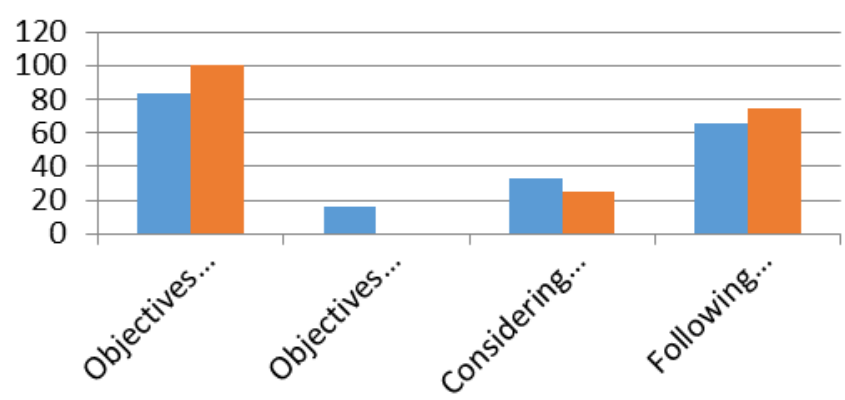

Elementary public school

Elementary non-public school

Table 5 Elementary school teachers in urban and rural area

\section{Elementary urban area Elementary rural area}

Sufficiently satisfied with the syllabus

$66 \%$

$50 \%$ 


\begin{tabular}{|lll|}
\hline Very satisfied with the syllabus & $33 \%$ & $50 \%$ \\
\hline Syllabus conformity with the learners' level/sufficiently & $83 \%$ & $100 \%$ \\
\hline Syllabus conformity with the learners' level/ a lot & $75 \%$ & $0 \%$ \\
\hline
\end{tabular}

\section{Graph 5}

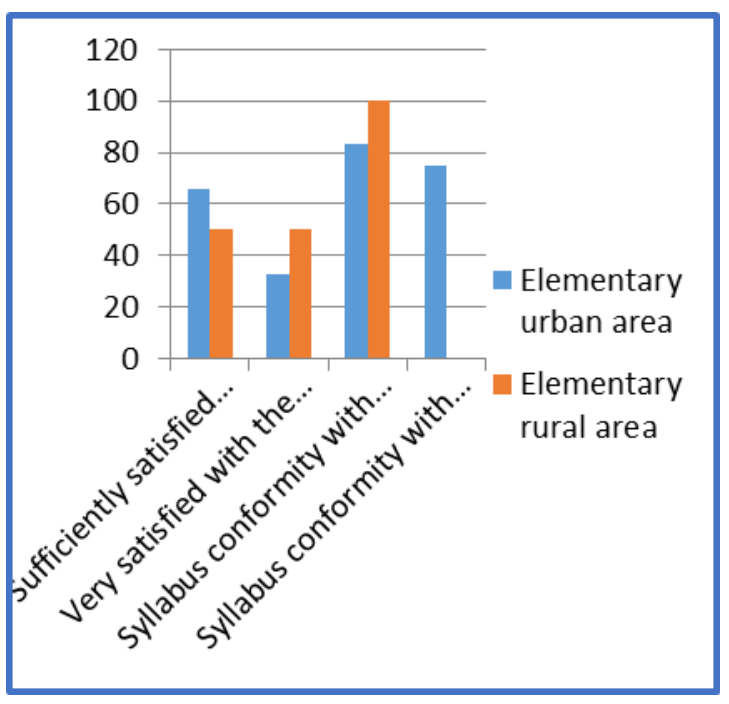

Table 6 Elementary school teachers in urban and rural area

\begin{tabular}{|lll|}
\hline & Elementary urban area & Elementary rural area \\
\hline Culture in syllabus $40 \%$ & $33 \%$ & $75 \%$ \\
\hline Culture in syllabus $80 \%$ & $66 \%$ & $25 \%$ \\
\hline Considering the learners'age/level $40 \%$ & $33 \%$ & $25 \%$ \\
\hline Considering the learners'age/level $60 \%$ & $0 \%$ & $75 \%$ \\
\hline Considering the learners'age/level $80 \%$ & $66 \%$ & $0 \%$ \\
\hline Syllabus objectives in textbook $20 \%$ & $16 \%$ & $0 \%$ \\
\hline Syllabus objectives in textbook $60 \%$ & $16 \%$ & $25 \%$ \\
\hline Syllabus objectives in textbook $80 \%$ & $33 \%$ & $50 \%$ \\
\hline Syllabus objectives in textbook $100 \%$ & $33 \%$ & $0 \%$ \\
\hline Syllabus conformity with CEFR $60 \%$ & $33 \%$ & $50 \%$ \\
\hline Syllabus conformity with CEFR $80 \%$ & $33 \%$ & $25 \%$ \\
\hline Syllabus conformity with CEFR $100 \%$ & $33 \%$ & $25 \%$ \\
\hline Syllabus realization $80 \%$ & $33 \%$ & $0 \%$ \\
\hline Syllabus realization $100 \%$ & $66 \%$ & $100 \%$ \\
\hline
\end{tabular}




\section{Graph 6}

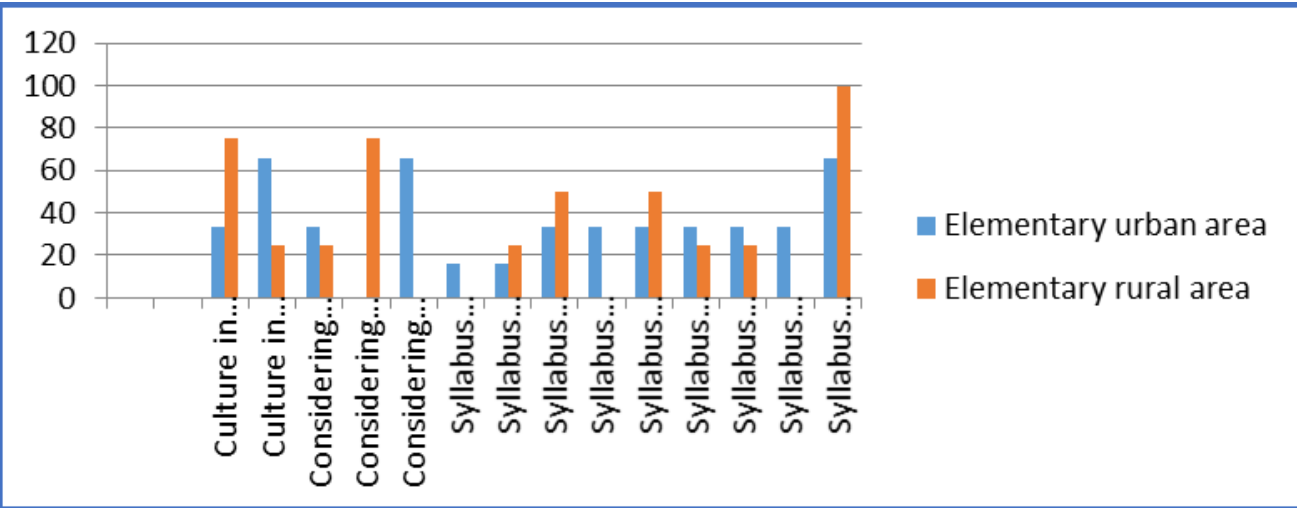

Table 7. Elementary school teachers in urban and rural area

\begin{tabular}{|lll|}
\hline & Elementary urban area & Elementary rural area \\
\hline Considering the learners' age & $100 \%$ & $100 \%$ \\
\hline Objectives presented in textbooks & $83 \%$ & $100 \%$ \\
\hline Objectives not presented in textbooks & $16 \%$ & $0 \%$ \\
\hline CEFR objectives in syllabus & $33 \%$ & $75 \%$ \\
\hline CEFR objectives not in syllabus & $33 \%$ & $25 \%$ \\
\hline $\begin{array}{l}\text { Objectives can be reached with a great nr of } \\
\text { learners }\end{array}$ & $50 \%$ & $100 \%$ \\
\hline $\begin{array}{l}\text { Objectives can not be reached with a great nr of } \\
\text { learners }\end{array}$ & $50 \%$ & $0 \%$ \\
\hline Assessment conform to CEFR/Yes & & $100 \%$ \\
\hline Assessment conform to CEFR/ No & $66 \%$ & $0 \%$ \\
\hline Introducing learners with objectives/Yes & $33 \%$ & $100 \%$ \\
\hline
\end{tabular}

\section{Graph 7}

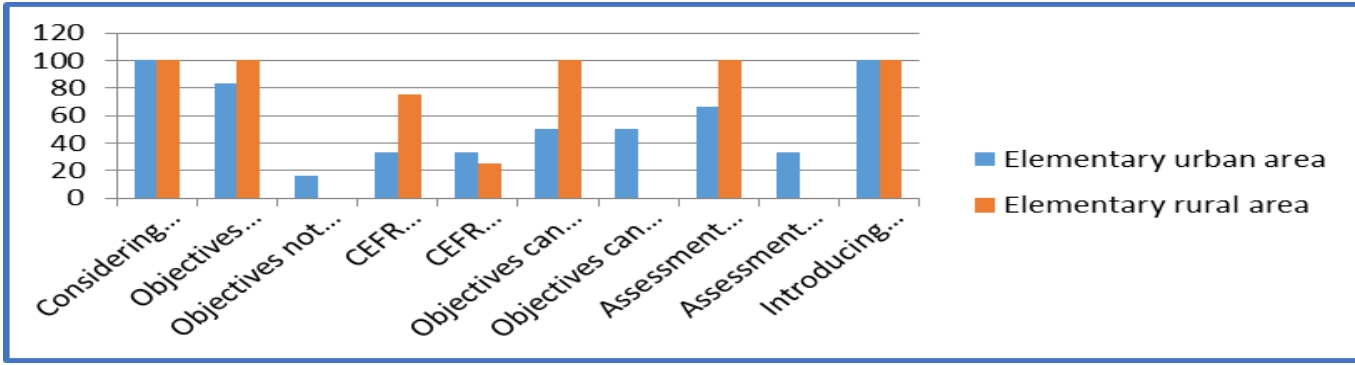


Table 8. Elementary school teachers in urban and rural area

\begin{tabular}{|lll|}
\hline & Elementary urban area & Elementary rural area \\
\hline Objectives set in every class & $83 \%$ & $100 \%$ \\
\hline Objectives set at the beginning of each chapter & $16 \%$ & $0 \%$ \\
\hline Considering learners'opinion for the syllabus & $33 \%$ & $25 \%$ \\
\hline Following the syllabus/not strictly & $66 \%$ & $75 \%$ \\
\hline
\end{tabular}

\section{Graph 8}

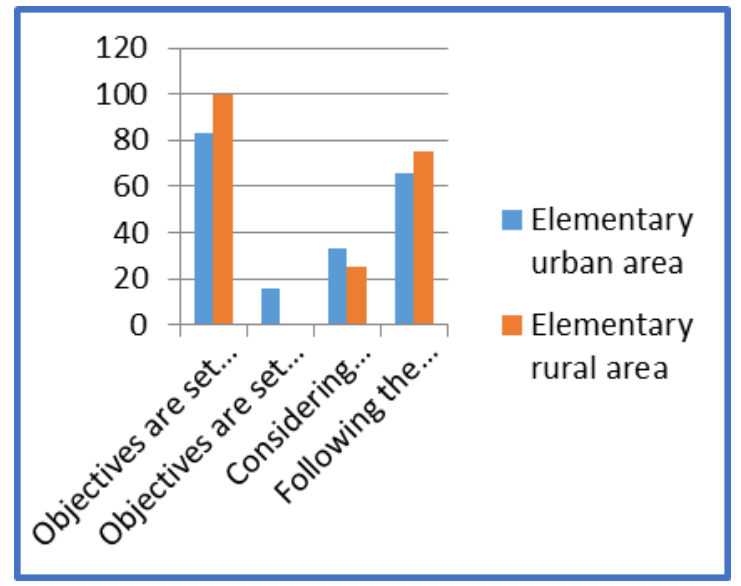

\section{Appendix}

\section{Questionnaire}

\section{Years in teaching:}

Textbook I use: Albanian/ Foreign authors

\section{I teach in:}

a) Elementary school public/nonpublic

b) Elementary school urban/ rural area

\section{Qualification:}

1.How much are you satisfied with the syllabuses?
a)A little satisfied
b) not satisfied
c) sufficiently satisfied
d) very satisfied

2. How much is the syllabus conform to the learners' level in the classes where you teach?
a) A little
b) Not conform
c) sufficiently
d) a lot

3. To what extent is the cultural aspect included in the syllabuses?
a) $20 \%$
b) $40 \%$
c) $60 \%$
d) $80 \%$
d) $100 \%$

4. Is the learners' level, age taken into consideration in the syllabuses?
a)Yes
b) No

5. If « yes » how percent is taken into consideration? 

a) $20 \%$
b) $40 \%$
c) $60 \%$
d) $80 \%$
d) $100 \%$

6. Are the syllabus objectives reflected in the textbooks?
a)Yes
b) No

7.

If "Yes", to what extent?
a) $20 \%$
b) $40 \%$
c) $60 \%$
d) $80 \%$
d) $100 \%$

8. Are the objectives of CEFR, reflected in the syllabus?
a)Yes
b) No

9.

If "Yes" are the syllabuses conform CEFR, and to what extent?
a) $20 \%$
b) $40 \%$
c) $60 \%$
d) $80 \%$
e) $100 \%$

10. Can the objectives of the English lesson be reached in classes with a great number of learners?
a)Yes
b) No

11. If "Yes" at what percentage?
a) $20 \%$
b) $40 \%$
c) $60 \%$
d) $80 \%$
e) $100 \%$

12. What is the number of learners in the classes where you teach?
15
20
25
30
40

percentage?

13. Is it created the possibility to work with appropriation of the 4 CEFR competencies? If "yes" at what

a)Oral comprehension....

b)Written comprehension....

c)Oral production ....

d)Written production....

14. Do you assess based on CEFR criteria's for assessment ?

$\begin{array}{ll}\text { a)Yes } & \text { b) No }\end{array}$

15. If "Yes" which assessment you mostly use ?

a)Formative assessment/ Summative assessment

b)Norm referencing assessment/ criterion referencing assessment

c)Continuous assessment/ Fixed assessment points

d)Direct assessment/ Indirect assessment

e)Subjective assessment/ Objective assessment

f)Holistic assessment / analytical assessment

g)Assessment by others/ self-assessment

13. Do you make continuous assessment? If "Yes" how?
a) During the year
b) at the end of modules?

16. Do you impose objectives and where?

a)In every class

b)In groups of classes

c)At the beginning of the units/ modules

17. Do you introduce learners with the objectives?
a)Yes
b) No 
18. How do you check how the objectives are reached?

19. Would you prefer:

a)Not to follow the syllabus

b)To consider learners' opinion for the lesson

c)To follow the syllabus but not strictly

d)Other......

20. Which linguistic skills do you give priority? (1-4) 1) a lot 4) a little:

a)Listening b) Speaking c) Reading d) Writing e) All of them based on CEFR criterias (Explain why).

21. To what extent is the syllabus designed by the Ministry of Education and Sport followed by you?
a) $30 \%$
b) $60 \%$
c) $80 \%$
d) $100 \%$

22. How often does the syllabus update?
a)Every year
b) Every two years
c) Every four years
d) more rarely 